Journal of MMIJ Vol.123 p.626-629(2007)

(C)2007 The Mining and Materials Processing Institute of Japan

\section{報告}

Technical Report

\section{佐賀関製錬所の銅製錬 *}

\title{
Copper Smelting and Refining at Saganoseki Smelter
}

\author{
by Takashi KIMURA ${ }^{\mathrm{a}}$
}

a. Deputy General Manager, Saganoseki Smelter \& Refinery, Nikko Smelting \& Refining Co.,Ltd., 3-3381 Saganoseki, Oita-shi, Oita, 879-2201 Japan

(Corresponding author E-mail : t-kimu@nikko-metal.co.jp )

In 1996 Saganoseki Smelter \& Refinery integrated its two flash furnaces to one in order to reduce the operating cost and maintain the global competitiveness.

And then many improvements were carried out to expand the smelting capacity.

However, the copper content in concentrates had been decreased and also the anode production was limited.

Therefore, the next project, which is called SPI (Saganoseki Process Innovation) project, was needed and started in 2003. In this project not only the smelting section but whole series of the process were modified and the productivity had been improved remarkably.

The activity of SPI project and operational changes of Saganoseki Smelter \& Refinery in the last decade are introduced in this paper.

KEY WORDS: Copper Smelting, Sulfuric Acid, Electro-refining, Copper Anode Slime

\section{1. 緒言}

佐賀関製錬所は 1916 年 (大正 5 年) に日本鉱業 ( 株 ) ( 現・新日 鉱ホールディング (株) ) の臨海買鉱製錬所として操業を開始した。

その後，数々の増強を繰り返し，1973 年に日鉱 (高温熱風) 式 自溶炉を 2 基有する世界有数の大型製錬所としての陣容を整えた。

さらに，資源開発，金属製錬・加工メーカーとして発足した日 鉱金属（株）の中核事業所として発展を続けた。とくに 1996 年 から 97 年にかけて, 自溶炉 1 炉化 ${ }^{1)}$ や独自の湿式法による銅殿 物処理操業を開始し ${ }^{2)}$ 国際競争力を強化した。

最近では (Fig. 1, Fig. 2)，さらなる競争力向上を目指し，SPI (Saganoseki Process Innovation) プロジェクトと称する所内全体に 渡る設備・操業形態の改革に取組んできた。

組織体制についても変革を遂行し，2006 年 4 月には，日鉱金 属 (株) と三井金属 (株) が共同出資する PPC (パンパシフィック・ カッパー (株) ) 社众下の製錬専業会社として日鉱製錬 (株) が設 立され，その主要事業所として新たなスタートをきった。

\section{2. 最近約 10 年間の経緯}

\section{$2 \cdot 1$ 溶錬および硫酸工程}

(1) SPI プロジェクト以前

* 2007 年 3 月 30 日受付 10 月 11 日受理

1. 普通会員 日鉱製錬（株）取締役 佐賀関製錬所 副所長

（現 苫小牧ケミカル（株）代表取締役社長）

[ 著者連絡先 ] FAX : 097-575-3513

E-mail : t-kimu@nikko-metal.co.jp

キーワード : 銅製錬, 硫酸, 電解, 銅殿物

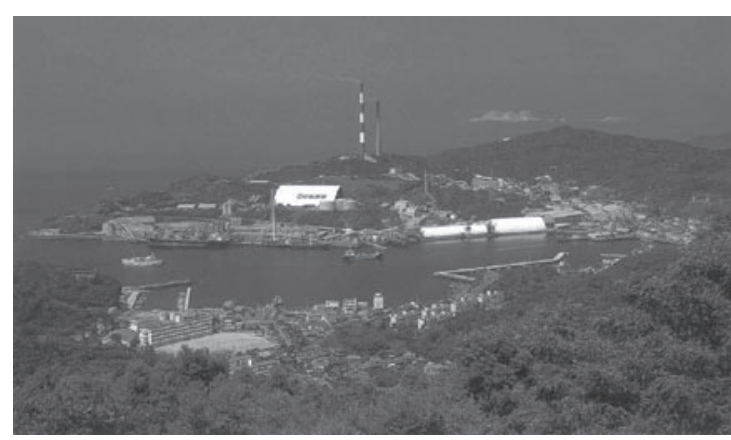

Fig.1 View of Saganoseki smelter \& refinery.

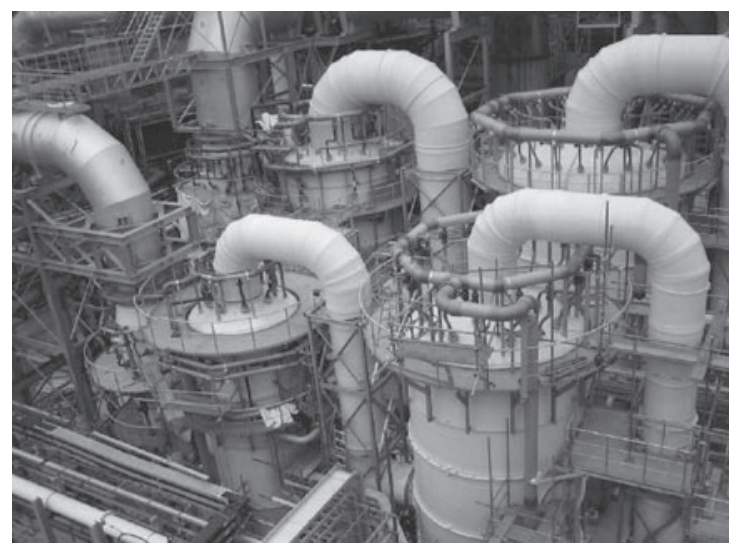

Fig.2 New gas washing \& cooling section in acid plant. 
Table 1 Main activities in SPI project.

\begin{tabular}{|c|c|c|}
\hline 工程 & 項 目 & 主なねらい \\
\hline \multirow[t]{7}{*}{ 溶鍊 } & 自溶炉鈹品位の上昇 $(65 \rightarrow 68 \%)$ & 鉱石増処理 \\
\hline & 自溶炉炉体冷却能力強化 & " \\
\hline & 溶剂ミルの新設 & " \\
\hline & 転炉集約 $(6 \rightarrow 4$ 炉 $)$ & コスト削減 \\
\hline & 転炉操業形態変更 (4 炉稼動 2 炉吹き $\rightarrow 3$ 炉稼動 2 炉吹き) & " \\
\hline & 排ガス道レイアウト簡素化 & " \\
\hline & 転炉ボイラ設置 & 省エネ \\
\hline 硫酸 & $\begin{array}{l}\mathrm{SO}_{3} \text { クーラー設置及びプレコンバーター設置 } \\
\text { ガス洗浄冷却設備の集約 }\end{array}$ & $\begin{array}{l}\text { 鉱石増処理、省エネ } \\
\text { コスト削減 }\end{array}$ \\
\hline 電解 & パーマネントカソード法導入 & 品質改善 \\
\hline 用役 & 酸素製造設備増強 (PSA × 2 基設置) & 鉱石増処理 \\
\hline \multirow[t]{2}{*}{ 物流 } & RORO 船導入 & コスト削減 \\
\hline & 新大型アンローダーの設置 & 鉱石荷役効率改善 \\
\hline
\end{tabular}

1996 年に競争力強化のため, 2 炉あった自溶炉を 1 炉に集約し た。その際, 粗銅生産能力 $330,000 \mathrm{t} /$ 年を保つため, 自溶炉炉体 冷却能力の増強, 新型精鉱バーナーの導入, 酸素製造設備の増強 ${ }^{3)}$ 等を行った。

その後，自溶炬ボイラーの増強 ${ }^{4)}$, 自溶炉鈹品位の上昇 $(62 \%$ $\rightarrow 65 \%$ ）による自溶炉鉱石処理能力の増強，転炉冷材投入設備 導入によって得られた送風停止時間短縮による転炉鈹処理能力の 増強等により, 2000 年には粗銅生産能力は 470,000t / 年に達した。

また, 硫酸工程においては, 2001 年にユーザーからの要請に 対応するため, 発煙硫酸製造設備を設置して, 製造・出荷を開始 した。

(2) SPI (Saganoseki Process Innovation) プロジェクト

上記の増産対応が一段落した後，銅鉱石の銅品位が低下する傾 向にあり,このため粗銅生産量の維持が困難になると予測された。 この問題に対応するために, 2003 年から 2007 年にかけて SPI プ ロジェクトを計画・実行し, 製錬所全体のより一層の効率化を図っ た (2007年 3 月完了)。このプロジェクトの概要を Table 1 に示す。 鉱石処理能力を増加させるため, 自溶炉鈹品位の上昇 $(65 \% \rightarrow$ $68 \%$ ), 自溶炉炉体冷却能力の強化, 溶剂ミルの新設, 酸素製造 設備の増強を実施した。

また，転炉についてもコスト削減と環境改善を目指し，設備の 集約化とあわせてレイアウトの見直しを行った。まず，炉内温度 管理強化等の操業改善により転炉炉寿命を 220 バッチから 350 バッチまで延長した。また, 転炉排ガス道レイアウトの簡素化を 図り, 老朽化していたガス道からのフリーエアを削減することで, 転炉送風量を増加させた。この転炉送風量増加により，転炉操業 形態を 4 炉稼動 2 炉吹きから 3 炉稼動 2 炉吹きに変更した。これ らの炉寿命延長と操業形態変更の結果，転炉を 6 基から 4 基に集 約することが可能となった。また，各転炉にそれぞれボイラーを 設置し, 廃熱回収能力を強化した。

硫酸工場では，老朽化して維持保全費が増大していた排ガス道 およびガス洗浄冷却設備を自溶炉系と転炉系の 2 系統に集約 (従 来 3 系統) して 1 箇所に建設し5), あわせて大幅にガス道を短縮 した。これにより維持保全費の削減とフリーエア量減少を達成す ることができた。また，鉱石処理能力増強と省エネルギーを目的 として硫酸製造工程において $\mathrm{SO}_{3}$ クーラーおよびプレコンバー ターを順次設置した。

さらに, 物流面では 2002 年に, 従来日立工場で行っていた鋳 返し溶解を休止することを前提として，当所と日立精銅工場との
間でやり取りするアノード，鋳返しの運搬専用の RORO 船を就 航させ，輸送の効率化を図った。続いて 2003 年には銅鉱石の荷 役効率の向上と近年の銅鉱石船の大型化への対応を図るため, 大 型アンローダーを設置した。

\section{$2 \cdot 2$ 電解工程}

電気銅の増産対応のため, 1998 年 12 月に第 3 電解工場の建屋 を増築してユニセル電解槽 80 槽を増設した。この増槽により, 第 2 , 及び第 3 , 第 4 各電解工場を合わせた電気銅生産能力は $252,000 \mathrm{t} /$ 年に増強された。その後, 2000 年 5 月に第 4 電解工場 の整流器を更新し, 平均電流密度 $280 \mathrm{~A} / \mathrm{m}^{2}$ 以上で電解操業を続 けていたが，電流効率を思うように改善できず，電流密度を徐々 に下げた操業を余儀なくされた。このため, 抜本的な電流効率改 善策として, 2006 年に当社日立工場で実績のあるパーマネント カソード法を導入することとした。

操業技術の改善としては, 電槽上における作業負荷の軽減と効 率化を図るため, 電極搬送クレーン用の位置決めピンの設置, 導 体インシュレーターの変更等の諸改善を実施した。

\section{$2 \cdot 3$ 殿物処理工程}

当社では,これまで銅電解殿物の処理工程を日立工場において, 乾式処理と電解精製を組み合わせた方式を採用してきたが，既存 設備の老朽化や生産性の向上に対応する必要がでてきた。

これら課題に対応するため, 湿式法による銅殿物処理プロセス を独自に開発し，1997 年 10 月以降，佐賀関製錬所内に新設した 工場で一貫した銅殿物処理を行ってきた。

その後, 2 回の設備増強工事や種々の改善を行い, 現在では金 : $3,500 \mathrm{~kg} /$ 月, 銀 (還元銀) : $31 \mathrm{t} /$ 月の生産能力を有寸る設備となった。

これに併せて銅殿物中のセレンを回収・製品化する工程につい てもプロセスの変更を行い, セレンの回収率向上と排水処理負荷 の低減を図ってきた。

\section{3. 最近の操業状況}

現状の製錬所全体の操業系統図を Fig. 3 に示す。

\section{$3 \cdot 1$ 溶錬および硫酸工程}

溶錬・硫酸工程の主要設備を Table 2 に示す。 近年の純生産粗銅量の推移を Fig. 4 に, 硫酸生産量の推移を

Fig. 5 に示す。

自溶炉 1 炉化，SPI プロジェクトを経て，佐賀関製錬所は高負 荷操業へ移行してきた。その代表的な指標として自溶炉装入速度 と鈹品位の推移を Fig. 6 に示寸。2006 年 11 月の定期修理以後の 


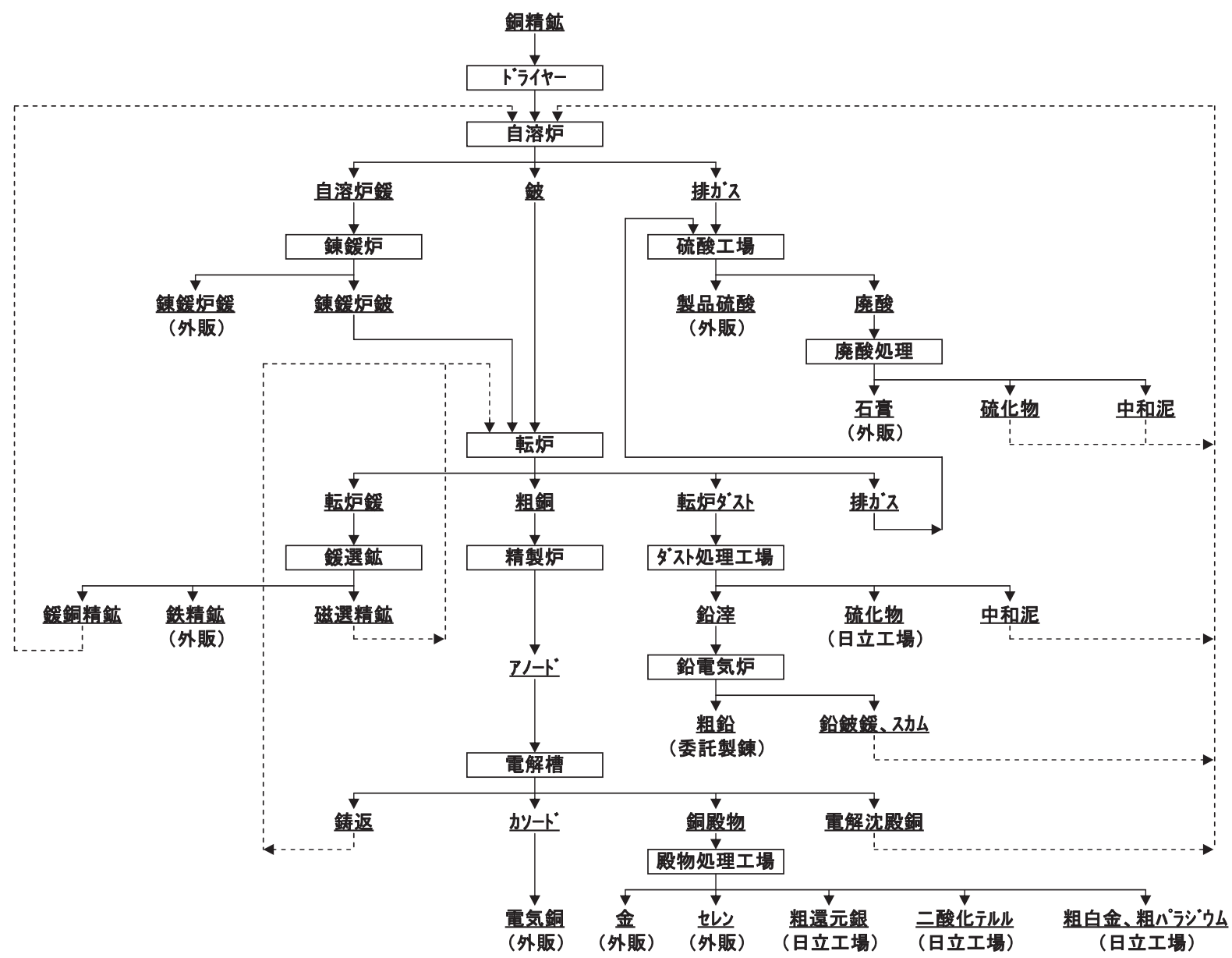

Fig.3 Process flow chart of Saganoseki smelter \& refinery.

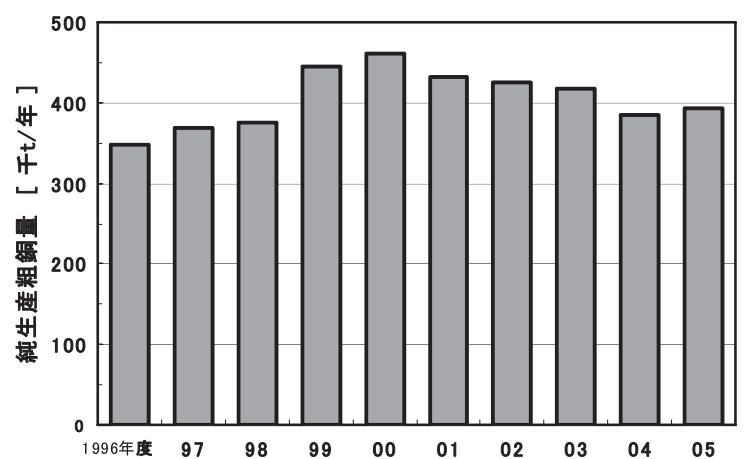

Fig.4 Transition of anode production.

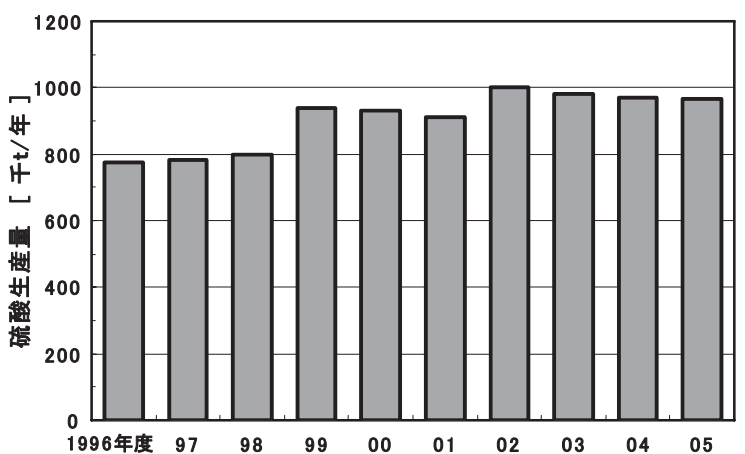

Fig.5 Transition of sulfuric acid production.
Table 2 Specification of main facilities in smelting \& acid plant.

\begin{tabular}{|c|c|}
\hline 設 備 名 & 様 \\
\hline $\begin{array}{l}\text { (1) 鉱石気流乾燥 } \\
\text { ロータリードライヤー }\end{array}$ & $\begin{array}{l}\text { 水分 } 9.5 \% \rightarrow 0.5 \% \text { 以下 } \\
2.4 \mathrm{~m} \phi \times 11 \mathrm{~mL}\end{array}$ \\
\hline $\begin{array}{l}\text { (2) 自溶炉 } \\
\text { シャフト } \\
\text { セットラー } \\
\text { 湯深 } \\
\text { 装入量 }\end{array}$ & $\begin{array}{l}5.9 \mathrm{mH} \times 6.2 \mathrm{mD} \\
21 \mathrm{~mL} \times 7.5 \mathrm{~mW} \times 2.1 \mathrm{mH} \\
1.2 \mathrm{~m} \\
210 \mathrm{t} / \mathrm{h}\end{array}$ \\
\hline (3) 錬鍰炉 & $\begin{array}{l}1.4 \mathrm{mH} \text { (湯深) } \times 9.0 \mathrm{mD} \text { (内径) } \\
3,000 \mathrm{kVA}\end{array}$ \\
\hline $\begin{array}{l}\text { (4) 転炉 } \\
\text { 天井クレーン }\end{array}$ & 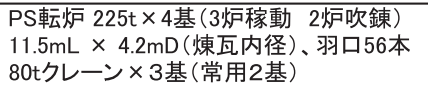 \\
\hline $\begin{array}{l}\text { (5) 精製炉 } \\
\text { 鋳造機 }\end{array}$ & $\begin{array}{l}400 \mathrm{t} \times 3 \text { 基 (LPG還元) } \\
11.2 \mathrm{~mL} \times 4.5 \mathrm{mD}(\text { 棟瓦内径)、羽口 } 2 \text { 本 } \\
\text { ウェンメック式 }(120 \mathrm{t} / \mathrm{h}) \times 1 \text { 基 } \\
\text { ウエンメック式 }(80 \mathrm{t} / \mathrm{h}) \times 1 \text { 基 }\end{array}$ \\
\hline $\begin{array}{l}\text { (6) ボイラ一設備·発電 } \\
\text { 発生蒸気能力 } \\
\text { 自溶炉排熱ボイラー } \\
\text { 転炉排熱ボイラー } \\
\text { 硫酸プレコンバータボイラー } \\
\text { 発電容量 }\end{array}$ & $\begin{array}{l}60 \mathrm{t} / \mathrm{h} \times 40 \mathrm{~kg} / \mathrm{cm}^{2} \\
16 \mathrm{t} / \mathrm{h} \times 40 \mathrm{~kg} / \mathrm{cm}^{2} \\
5.5 \mathrm{t} / \mathrm{h} \times 40 \mathrm{~kg} / \mathrm{cm}^{2} \\
\text { タービン発電機的, } 12,000 \mathrm{~kW} \\
\text { ディーゼル発電機 } 14,950 \mathrm{~kW}\end{array}$ \\
\hline （7）酸素製造設備 & $\begin{array}{lr}\text { 深冷式 } & 24,000 \mathrm{Nm}^{3}-\mathrm{O}_{2} / \mathrm{h} \times 1 \text { 基 } \\
\text { PSA式 } & 4,000 \mathrm{Nm}^{3}-\mathrm{O}_{2} / \mathrm{h} \times 2 \text { 基 }\end{array}$ \\
\hline $\begin{array}{l}\text { (8) 硫酸·排煙脱硫 } \\
\text { 硫酸工場 } \\
\text { 硫酸生産量 } \\
\text { 排煙脱硫 } \\
\text { 石育生産量 }\end{array}$ & 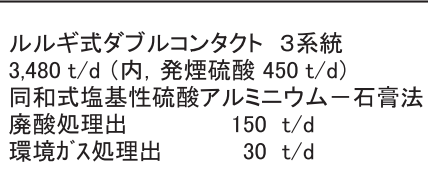 \\
\hline
\end{tabular}




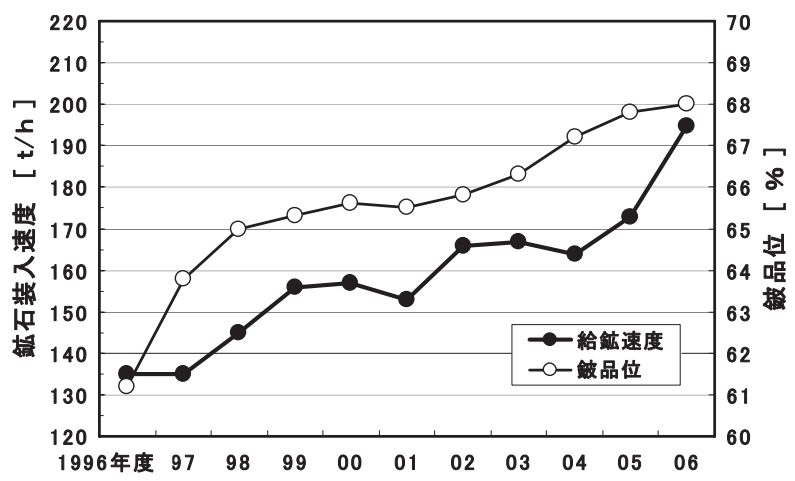

Fig.6 Feed rate and matte grade in flash furnace operation

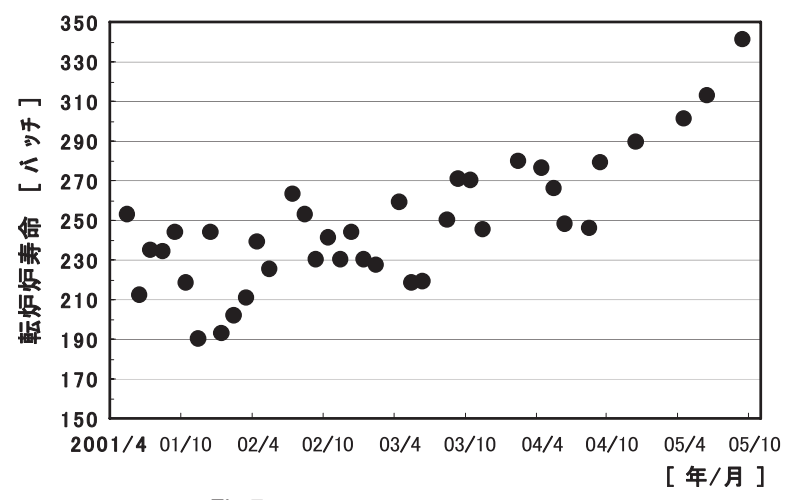

Fig.7 Campaign life of PS converter.

鉱石装入速度 (繰返しダスト除き) は $200 \mathrm{t} / \mathrm{h}$ を超え, 最大 $212 \mathrm{t} / \mathrm{h}$ で操業を行っている。

また，SPIプロジェクトの主要課題として取り組んだ転炉炉寿 命延長について, その推移を Fig. 7 に示寸。

\section{$3 \cdot 2$ 電解工程}

最近 10 年間の電気銅生産量の推移を Fig. 8 に示す。 2000 年ま では生産量が増加していたが, それ以降はやや減少傾向にあった。 電解工程において特筆すべきは, SPI プロジェクトの一環として, 2006 年 第 3, 第 4 電解工場にパーマネントカソード法を導入し た点である。

2005 年 4 月よりカソード剥取機の建設工事を開始し，2005 年 12 月から 2006 年 1 月にかけては第 3 , 第 4 電解工場の整流器能 力の増強を行った。2006 年 9 月より第 3 , 第 4 電解工場のパーマ ネントカソード化を順次進め, 同年 12 月に全カソードの変更を 完了し，パーマネントカソード電解操業法の本格稼動となった。

本格稼動後, 電流密度を段階的に引上げ，現在は平均電流密度 $300 \mathrm{~A} / \mathrm{m}^{2}$ で安定した操業を継続しており，今後はさらに $320 \mathrm{~A} / \mathrm{m}^{2}$ へと引き上げてゆく予定である。

なおこの操業法変更を契機に，小規模且つ老朽化の問題を抱え ていた第 2 電解工場は休止することとしているが, 当社の電解能力 は日立精銅工場とあわせ, $450,000 \mathrm{t} /$ 年を維持することとしている。

\section{$3 \cdot 3$ 殿物処理工程}

近年の取り組みとして, 殿物処理コストの削減と原単位の低減 を図ると共に，生産面においては，ショット金の増産，及び白金 の抽出・精製工程における製品直行率の改善等の課題を克服し, 更なる収益の改善と増産を目指している。金生産量の推移を Fig. 9 に示す。

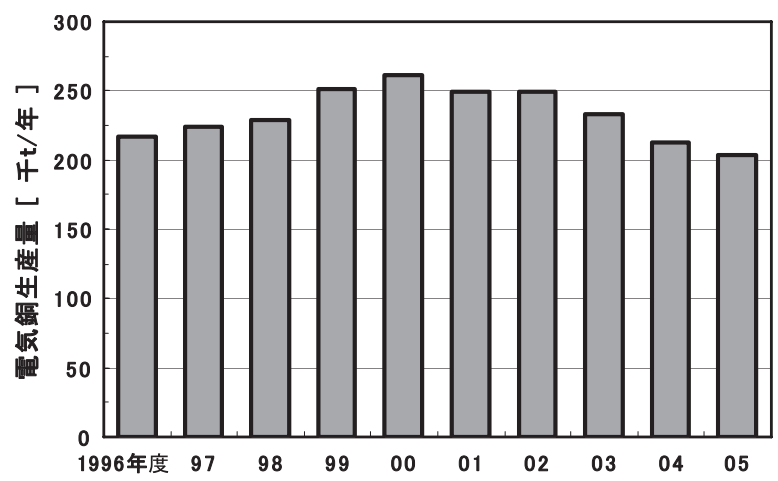

Fig.8 Transition of cathode production.

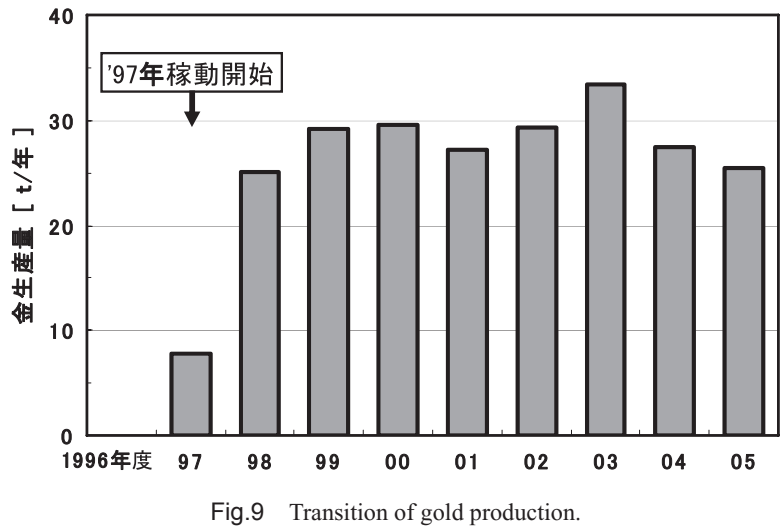

4. 今後の展望

ここ数年, 当製錬所は相次いで大型の設備投資を実行してきた。 今後は, 安全・環境の確保を大前提に, 安定した操業の維持継続 に取り組むとともに，次に示すような課題に取り組んで行きたい と考えている。

(1)さらなる製錬工程の効率化とコストダウン

(2) スラグ等の副産物有効利用の促進

(3) 銅製錬本体と有価金属リサイクルの組合せの最適化

(4)省エネルギーの推進

5. 結言

当所は製錬専業会社として日立精銅工場とともに独立して新た なスタートきったが, その一方, PPC 社グループの一員として国 内では日比共同製錬 (株) 玉野製錬所と, 海外ではLS-Nikko（株） 温山製錬所とも連携を深めてきている。今後これらのグループ内 製錬所間で共有できるハード・ソフト両面にわたる資産を活用し, 新たなシナジ一効果を最大限に発揮させることを目指している。

独自技術の進化を図りつつ, 所外の英知も取り入れながら, 操 業開始百周年に向けての次なる 10 年を持続的発展の可能な製錬 所づくりに向けて努力していきたい。

\section{References}

1) M. Ishikawa: Journal of MMIJ, 114(1998), 447-454

2) A. Toraiwa and Y. Abe: Journal of MMIJ, 116(2000), 484-492.

3) G. Tanaka, S. Nogami and K. Kurose: Journal of MMIJ, 112(1996), 424-427.

4) T. Fujii, Y. Suzuki and M. Hoshi: Journal of MMIJ, 116(2000), 428-431.

5) H. Nakata and T. Yamaki: Shigen-Sozai Journal of MMIJ, 121(2005), 166-169. 